By H. T. PAYNE

\title{
The Junior College Library and the Student
}

Mr. Payne, a student at the Virginia Junior College, gave this, the third paper in the symposium of the Junior College Libraries Section, June 25, 1942.

$\mathrm{E}^{\mathrm{v}}$ VERY STUDENT when he enrolls in school, be it a college or a university, is aware of two things. First of all, he knows that most of his time is going to be taken up with studying and the majority of that studying will be done from books. Furthermore, he is aware that he is going to acquire, in some measure at least, that elusive quality, culture. Here, too, books will play an important part. For the most part this reading will be done from textbooks, but there is an additional minimum of required reading which must be done from supplementary books.

We might well ask whether or not a junior college library is really necessary. Why not make use of the public library, where such is available, rather than go to the trouble and expense of providing an additional school building?

Being a student, I am unfamiliar with the technicalities of library planning and problems, and shall confine myself, therefore, to presenting the question from the standpoint of the student-something like the meditations of a guinea pig at the conclusion of an experiment in which he was the principal character involved.

It might be said by some that where a well-stocked public library is available, a junior college library is unnecessary. Surely, the public library has plenty of books for the student who wishes to use them, and facilities for study are not lacking.

All this is true enough as far as it goes, but it doesn't go far enough. It isn't a question simply of the number of books available, but are they the kind needed? We may have all the facilities for study we need, but if the atmosphere of study is lacking, no amount of aids will help. As Dean Moe has so ably pointed out, the library is something more than a department, it is a "powerhouse." When it becomes merely a dispenser of books, it seems to me that it defeats its purpose.

The public library of necessity caters to the general public, whereas the junior college library concentrates-or at least it should-its attention on the needs of the student. Many a "superior" student has remained in the "average" bracket simply because the proper books for his supplementary reading were not available.

Furthermore, a great deal of the student's time between classes and after school is spent in the library where he has not only the facilities for study but the atmosphere as well-not that he always avails himself of the opportunity.

Quite often the approach of a student to the library is dependent on the inspiration, or lack of it, he receives from his instructor. This places a certain amount of 
responsibility on the part of the instructor to not only inform himself as to the contents of the library but also to cooperate in interesting the student in its proper value.

The library, too, can do much to assist and encourage the student to make use of the books lining its shelves. The required reading will more or less take care of itself, but some effort must be made to interest the student in things other than facts and figures. He must be shown that books are not only medicine to be taken for one's intellectual health but are friends worth cultivating and respecting.

As has been stated, the library is more than just a dispenser of printed material ; it is a powerhouse and should endeavor by periodic displays and other pertinent programs to arouse the interest of student and instructor alike.

Thus far I have placed the whole burden on the shoulders of the library and instructor, apparently absolving the student from any responsibility whatever. The student, however, is not like a sponge ball bounced about between the walls of learning absorbing, or refusing to absorb, whatever he comes in contact with. No matter how great his opportunities, they are wasted until he applies himself and avails himself of them.

The student should learn to use his library as a place of mental recreation and stimulus as well as for study. Once the technicalities of the indexes, file boxes, and references are mastered he will find the library has a character all its own.

He should spend an hour or two whenever possible doing nothing but browsing. Handle the books, become familiar with their size and shape, color and design. Each book has a personality of its own, seldom revealed by its call number. There is a pleasant mustiness about an old book, a crisp vigor about a new book which can only be known through actually handling them.

As a student I would say, therefore, that the junior college library is important as a source of supplementary textbook reading, a convenient and congenial place for study and for acquiring a greater knowledge through the thoughts and lives of men of all ages.

\section{Field Library Services of the U.S. Department of Agriculture Library}

\section{(Continued from page 40)}

perhaps not communicated to you more than a factual statement concerning the groundwork which has been laid the past eleven months and has not indicated to you the vastly interesting nature of the job. As Gaus and Wolcott ${ }^{1}$ have pointed

\footnotetext{
1 Gaus, J. M., and Wolcott, L. O. Public Administration and the United States Department of Agriculture. Chicago, Public Administration Service, I 940 . $534 \mathrm{p}$.
}

out, except for an over-all picture, the work of the department should be viewed not from its Washington center but from studies from its regional centers. The really stimulating and interesting papers about our field work will be written by the field librarians themselves who will have firsthand stories to tell. 